\title{
Spatial pattern and developing mechanism of railway geo-systems based on track gauge:
}

\section{A case study of Eurasia}

\author{
WANG Chengjin ${ }^{1,2,3}$, LI Xumao ${ }^{1,2,3}$, CHEN Peiran ${ }^{1,2,3}$, XIE Yongshun ${ }^{1,2,3}$, \\ LIU Weidong ${ }^{1,2,3}$
}

1. Institute of Geographic Sciences and Natural Resources Research, CAS, Beijing 100101, China;

2. Key Laboratory of Regional Sustainable Development Modeling, CAS, Beijing 100101, China;

3. College of Resource and Environment, University of Chinese Academy of Sciences, Beijing 100049, China

\begin{abstract}
The railway is an indispensable feature of a nation's infrastructure, and the gauge is an internal and objective technical regulation of the railway. In the large-scale regional space, the track gauges reflect the development differences, historical relations and mutual influences between countries and regions. This makes the railway, originally as a regional connection, have special social, political, military and other multiple attributes. Based on this, the paper, from the perspective of railway gauge, takes the Eurasian continent as the case region to explore the spatial pattern, formation mechanism and organizational mode of communication of the Eurasian continental railway geo-system. The results show that 11 kinds of railway gauge structures exist in Eurasia, which respectively belong to three types of wide-gauge, standard-gauge, and narrow-gauge, but the mainstream gauge only includes $1520 \mathrm{~mm}, 1435$ $\mathrm{mm}$ and $1067 \mathrm{~mm}$. Considerable variation in the coverage length and space range of different gauges is apparent, which provides a physical and technological basis for railway system differentiation and network fragmentation, which leads to the formation of eight railway geo-systems. Due to different modes for railway transport management in different geographical locations, the geographical pattern and geographical relationship of four transport organizations are formed. What especially important is the emergence of "1435 gauge space" and "1520 gauge space", as well as the railway geo-space confrontation between them, on the Eurasian continent. Besides, we also find that the railway geo-system of Eurasia is mainly affected by the technology dissemination, path dependence, geopolitics, national defense and the colonial expansion of military latitude, and on this basis, five geo-modes of railway gauge propagation are formed.
\end{abstract}

Keywords: railway; railway geosystem; development mechanism; expansion mode

Received: $2020-02-28$ Accepted: $2020-05-22$

Foundation: The Strategic Priority Research Program of the CAS, No.XDA20010101; The Key Project of the Chinese Academy of Sciences, No.ZDRW-ZS-2017-4

Author: Wang Chengjin, PhD and Professor, specialized in economic geography, especially the port system, logistics network, and industrial geography. E-mail: cjwang@igsnrr.ac.cn 


\section{Introduction}

Transportation facilities are basic components of a national infrastructure system and play a role in national defense and military activities. For a long time, transportation facilities and networks have played an important role in national economic activity, social exchanges, political domination, and international geopolitical competition (Jin et al., 2010). Before the Industrial Revolution, the main modes of transportation for human society were road and water transport (Spence et al., 1994). Since the Industrial Revolution, railways have become the most important mode of transportation, and have profoundly affected the economic development, social progress, national stability, and even international relations of various countries. The relationship between transportation facilities and regional development has always been a core feature of transportation geography research (Linneker et al., 1996), especially accessibility and space-time convergence (George, 1999). However, the safety and political attributes of transportation have not been seriously considered, including the relationships between transportation and national security and transportation and geopolitics. Some researchers believe that transportation technology is the foundation of space control capabilities, while it has also been reported that railways are very important for national integration (Jin et al., 2004). Bel (2011) suggested that each country should regard road construction as an important means of integrating and operating state power, but road construction alone would be insufficient to meet this objective. Lu (2005) and Wan (2009) believed that transportation technology is an important factor affecting and restricting geopolitics, and is also a core component of changing geopolitical relations and styles. A railway network has important national defense and military functions. Zhou (1990) and Li et al. (2007) analyzed military transportation capabilities. The improvement of the national defense and military functions of a railway network influences on geopolitics (Li, 2008). Li Zhenfu and $\mathrm{Wu}$ (2016) believed that the expansion of a transportation network can change the international development space and even alter national geographical relationships. Che (2010), Nie and Zhao (2012), Ma and Liu (2010), Li and Wu (2016), and other researchers have analyzed the impact of railways on geopolitics from a domestic perspective. Wei (2017) and Ren (2009) analyzed the impact of railways on the international geopolitical landscape. The geographical location of a railway remains unchanged, while national boundaries may change. This will cause spillover effects beyond those imposed by physical boundaries, with a particularly strong impact on traffic flow (Saul, 1973). Many researchers have analyzed the geopolitical problems of Eurasia, including Li (2016), Sun (2016), Kolotov (2016), Wan (2016), and Jing (2016). The United Kingdom established a standard track gauge for railways in 1846. However, different countries subsequently used various gauges to build railways because of their different national conditions, which has resulted in a variety of track gauges being in use around the world. The physical positioning of a railway cannot be influenced by improvements in the wider environment. The basis of overall regional integration is the integration of transportation networks, resulting in low transportation costs (Gan et al., 2010), and many researchers have investigated their relationship (Nie et al., 2012). Li (2011) analyzed the integration of the Eurasian railway network. Ba and Guan (2009) analyzed the economic mechanism that has led to track gauge differentiation, while some researchers have investigated the conflicts in international transportation generated by the dif- 
ferences in railway networks (Zeng et al., 2019). The existing research has attempted to produce a simple and qualitative description of the significance of railways in national defense at the macro level, which has tended to reveal the geopolitical significance of a single railway line. For a long time, little concern was expressed regarding the differences in track gauges and the influence of track gauges on geopolitical patterns was not considered by researchers. Even less attention has been given to an analysis of the dynamic mechanisms leading to the formation of the existing patterns. We selected Eurasia as the research area to first reveal the structure of the track gauges in the existing railway network and their distribution among different countries, and we then analyzed the geo-systems that influenced the pattern of differentiation. Finally, we analyzed the dynamic mechanisms leading to the development of the existing rail networks and consolidated the results as a geopolitical model.

\section{Concepts and data}

\subsection{Definition of concepts}

It is an important research purpose and basic paradigm of human geography to describe the spatial differentiation law and spatial structure of human activity system on the surface of land (Mao, 1995; Fan, 2008). Wu put forward the concept of regional system of human-earth relations in 1979, believing that the special field of geography is to study regional system of human-earth relations (Fan et al., 2016). Spatial structure, time process, organizational order change, etc., are important aspects of understanding the systematic optimization and regulation mechanism of human-earth relationship on different scales (Wu, 1991). This is an important theoretical cornerstone of human geography ( $\mathrm{Lu}, 2002)$. Regions are composed of a series of basic units, which are represented as a number of smaller microscopic units in form and different geographical elements in content. The regional system is a relatively independent and complete spatial system with specific attributes or unified functions formed by the combination and interaction of these different units and elements in space and the adjacent connection between them. The difference or zonality of natural endowments, the incomplete separability of economic activities and the indelibility of spatial distance are the objective basis for the formation of regional system. Geo-environmental system is an important type of regional system. Hu (2013) thought that geo-environmental system is a special composite system with certain structure and function. It is the result of mutual influence and interaction among several subsystems, such as geopolitics, economy, society, military and ecological environment, within the geographical environment constituted by specific geographical bodies.

The differentiation of geographic space, its influence on the pattern of human geography, its process of action and its development mechanism are important research topics (Fan, 2008). After a long period of human construction and development, the macroscopic structure and social and economic development patterns of the earth surface have undergone remarkable changes. In particular, since the Industrial Revolution, the railway has become an important part and material facilities of the earth's surface, which has formed a powerful intervention in the interaction and functional properties of various regions of the earth's surface and reshaped the global space structure. The continuous construction, network expansion and network connection of the railway not only improve the openness of the country 
but also strengthen the closure of the country, which shapes the geography between countries and promotes the formation of the unique attributes of the railway, such as "networked", "regional" and "geopolitical". The railway geo-system is a special type of regional system. Based on the railway infrastructure network and the railway transportation network in a specific region, it integrates railway, state, rights, and other contents, and integrates economic, natural, social, national defense and military elements, so as to form an interactive and interdependent geo-environmental system. It has the same railroad technical standard or forms the unified transportation rule, in the space railroad joins each other into the network, the country borders the distribution forms the continuous space. The elements of the railway geo-system are similar to other geo-environmental systems, including political, economic, military, socio-cultural, ecological, natural environment and other elements. But it is an essential scale for defining space.

The railway geo-system synthetically integrates different concepts such as railway network, geo-relation and regional system, which not only has the general characteristics of the human-land relation regional system but also has the particularity of the geo-environmental system. Besides, it also has the common attributes of the regional system and the geo-environmental system. In summary, typical characteristics mainly include the following aspects. (1) The core performance of the railway geo-system differentiation is railway gauge and transportation rules, the former reflects the technical fracture of physical facilities, the latter emphasizes the management fragmentation of human intervention. (2) The continuity of the space and the border with the country are the typical morphological characteristics of the railway geo-system. The national railways in the same system are connected in a network, which is manifested by rail connection and uniform transport rules. This is the basis of the "networked". (3) Railways are always associated with a certain amount of space. Geographical location and spatial distance are the premise of determining regionalism. The state is the spatial defining unit of the unification of railway technical standards. Within the railway geo-system, countries are contiguous and continuously distributed in space. In a large geographical area of the world, railway technology and transportation rules are unified. The continuity of space, the unification of technology and the unification of rules determine the "regionalism" of the railway geo-system. (4) The relationship between different railway geographic systems is different, but it is mainly dominated by confrontation and supplemented by cooperation. The confrontation mainly reflects the economic, socio-cultural and even defense military and geopolitical confrontation through railway transportation (including goods, passengers and military transportation). This is the basis for the formation of "geography" or "closure". Cooperation is mainly about the exchange of energy, raw materials, products and people with other neighboring systems. (5) The status of each country in the railway geo-system has formed different types due to historical relations. The mainstream has different discourse right and forms the dominant position or priority in the communication of railway technical standards and the formulation of transportation rules. It should be noted that the dominant state may come from outside the geopolitical system. Countries within the geographic system may also form the same right of discourse but not the dominant power. (6) The functions of the railway geo-system include security and development. The "transportability", "network" and "regionalism" of the railway geo-system determine that its basic function is development. It attaches importance to the cooperation 
and exchanges, mutual complementarity and mutual promotion among the member states within the system, with the emphasis on economic development and cultural exchanges, mainly for internal purposes. Technical segmentation, rule segmentation and "geography" determine that the basic function of the railway geo-system is safety.

\subsection{Data and sample}

The sample selection was key to the analysis undertaken in the study. (1) It was important for the research area to have a long history of development and a complex geography. We selected the Eurasian continent as the research area. The geographical environment of Eurasia is complex and the socio-economic development of different regions is very different. There have been longstanding conflicts and population integrations among different ethnic groups, civilizations, and countries of Eurasia, resulting in complex geographical relationships. The "sectarian-colonial" system has historically been in place throughout the region and has established the land rights doctrine. Eurasia was the first location in the world to experience industrialization and the countries of the continent have continued to expand and upgrade their industrial base. The earliest railways were constructed in Eurasia, and the railway network is the largest and most complete in the world. (2) Our research object was the railway network. There are various types of railways, each with different functions, including public transport, mining and forestry, tourism, park, and special-purpose railways. Public transport railways are oriented towards social publicization. The transport of goods and passengers is the main function of this type of railway. It is the most common type of railway and forms a systematic network. Therefore, the research data we used was mainly based on the analysis of public transport railways that formed a unified network. (3) We used 92 individual countries as the spatial unit for the analysis conducted in this study. The sampled countries covered an area of more than 53.4 million $\mathrm{km}^{2}$, accounting for $36 \%$ of the total land area of the world, more than 5 billion people (i.e., three-quarters of the world's total population), and $60 \%$ of the world's total economy. (4) The data used in the study was mainly obtained from maps from the World Atlas published by the China Map Publishing House in 2018. The railway gauge data are mainly from the national railway administration of China, Co-operation between Railways (OSJD) and International Rail Transport Committee and other international organizations (CIT).

\section{Structure of the Eurasian railway gauge}

Any transportation facility has its inherent technical regulations. In particular, certain core regulations determine the matching and follow-up of some technical indicators, which leads to system differentiation. A nation's railway network is the main artery of its economy and the prescriptive nature of the core technologies used and the differentiation of the network have a large influence on its operation. A railway track is a piece of railway infrastructure that usually consists of two balanced rails. The track gauge is the inner distance between the two rails of the railway. When constructing bends in a railway, the gauge should be appropriately widened according to the radius of a curve, with an allowable error of up to $4 \mathrm{~mm}$ and a minimum of $2 \mathrm{~mm}$. This is the technical and physical basis for determining the differences in the formation of a railway system and the formation of fractures in the network. (1) 
Track gauges are complex and diverse because they differ among countries with different national conditions and in different areas where external influences can intervene. According to the differences in gauge width, rail networks can be categorized as wide-gauge, standard-gauge, and narrow-gauge railways. The International Railway Association stipulated that the $1435 \mathrm{~mm}$ gauge was the international standard in 1937. According to this standard, the gauge width can be determined using two classification methods. The first method uses the standard-gauge, wide-gauge, and narrow-gauge categories. The wide-gauge is wider than the standard gauge of $1435 \mathrm{~mm}$, while the narrow-gauge is narrower than the standard-gauge. The Eurasian railway network has about $381,300 \mathrm{~km}$ of standard-gauge railways, accounting for $53.9 \%$ of the total length of railways in the region. Although this is $7 \%$ less than the global average, it is the most widely used gauge width worldwide. The length of a wide-gauge ( $\mathrm{L}>1435 \mathrm{~mm}$ ) railway in the Eurasian railway network is $264,300 \mathrm{~km}$, with a specific gravity of $37.4 \%$, and is $16.5 \%$ less than the length of the standard-gauge railway. The length of the narrow-gauge $(\mathrm{L}<1435 \mathrm{~mm})$ railway in the Eurasian railway network is $61,500 \mathrm{~km}$ with a specific gravity of $8.7 \%$, and is $45.2 \%$ less than the length of the standard-gauge railway and $28.7 \%$ less than the length of the wide-gauge railway. Most narrow-gauge railways have a $1000 \mathrm{~mm}$ gauge width. In the second classification system, a track gauge of more than $1520 \mathrm{~mm}$ is considered a wide-gauge and a track gauge of less than $1067 \mathrm{~mm}$ is considered a narrow-gauge. The track gauge of a railway can, therefore, be divided into five classes: $\mathrm{L}>1067 \mathrm{~mm}, 1067 \leqslant \mathrm{~L}<1435 \mathrm{~mm}, 1435 \mathrm{~mm}, 1435 \leqslant \mathrm{~L}<1520 \mathrm{~mm}$, and $\mathrm{L}<1520 \mathrm{~mm}$. This classification is based on the fact that the $1067 \mathrm{~mm}$ gauge railway is the longest and most widely distributed narrow-gauge railway in the world. The $1520 \mathrm{~mm}$ gauge is the longest and most widely distributed wide-gauge railway in the world. Both are used in many countries. These two gauge lengths have therefore become the threshold for the division of gauge type. (2) Slight differences in the gauge width of railways are crucial in the formation of a railway network. Although the 1435 and $1520 \mathrm{~mm}$ gauges are the main gauge widths used in the Eurasian railways, the 1676 and $1067 \mathrm{~mm}$ gauges are also important, as shown in Figure 1. Most of the wide-gauge railways are $1520 \mathrm{~mm}$ gauges, with a mileage of $175,400 \mathrm{~km}$, accounting for $24.8 \%$ of the length of the Eurasian railway network. Railways with the $1676 \mathrm{~mm}$ gauge width extend for $52,800 \mathrm{~km}$, accounting for $7.47 \%$ of the network. Within the wide-gauge railway network, railways with a $1520 \mathrm{~mm}$ gauge width account for $66.35 \%$ of the network, while railways with a $1676 \mathrm{~mm}$ gauge account for $20 \%$. Among the narrow-gauge railways, the $1067 \mathrm{~mm}$ gauge width accounts for most of the network, although there is also some railway with a $1000 \mathrm{~mm}$ gauge width. The length of the railway covered by the two gauge widths is 37,600 and $21,400 \mathrm{~km}$, accounting for $5.32 \%$ and $3.02 \%$ of the total length of the Eurasian railway network, respectively. The two gauge widths account for $61.2 \%$ and $34.8 \%$ of the Eurasian narrow-gauge railway network. (3) The differences in the distances covered by different gauge widths have led to an incompatibility in railway technical standards, which has resulted in the railway network developing the spatial phenomenon of "formally forming a network and disconnecting the network." This is manifested by trains that run on different gauges being unable to pass through the entire network. Therefore, to facilitate international railway intermodal transport there is a need to change the train bogies and wheelsets. This not only increases transportation costs but also extends transportation time. The trains used in the Eurasian railway net- 
work are now unable to pass through the entire network because the Soviet Union has adopted the $1520 \mathrm{~mm}$ wide-gauge, while the EU countries and China have adopted the $1435 \mathrm{~mm}$ standard-gauge. This has extended the transportation time from the original 8 days to 14-15 days.

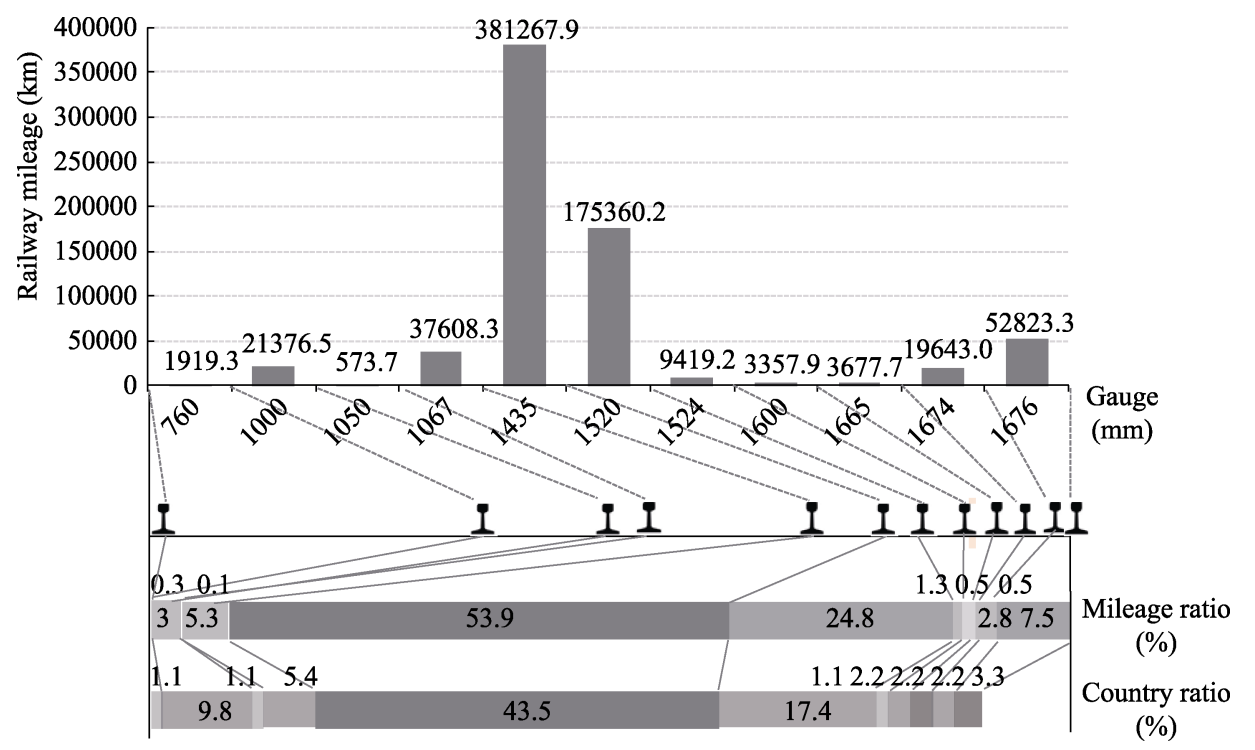

Figure 1 The length of different track gauges within the railways of Eurasia

Figure 2 shows the spatial distribution of the Eurasian railway network and its different gauge widths. From a spatial perspective, the rail gauges used in different countries are significantly different, which has led to the operation of a variety of different gauge railways in the Eurasian region. Many track gauges have their common names, which are mostly related to geographic locations or regional terms. This reflects the regional nature of the gauge widths used in railways. However, the coverage of the railway network among different countries varies because the gauges are different, with the following specific features. (1) Most countries have railways with multiple gauges, and there is no country with only one gauge railway. There are many different track gauges in China, Japan, and other countries. However, in most countries, it is common for a certain track gauge to be used in most railways, while others are used in special situations or in historic networks that have been preserved for various uses. Based on this, we were able to devise a classification system for each country that uses railways with a gauge width in the range of 610-2141 $\mathrm{mm}$. (2) There are six different gauge widths used in the wide-gauge railways $(1520 \mathrm{~mm}, 1524 \mathrm{~mm}, 1600$ $\mathrm{mm}, 1665 \mathrm{~mm}, 1674 \mathrm{~mm}$, and $1676 \mathrm{~mm}$ ), which are widely distributed throughout 26 countries in Eurasia. The $1520 \mathrm{~mm}$ gauge width is commonly known as the "Soviet gauge." This type of railway is the most widely distributed throughout the region, covering 16 countries including Russia, Kazakhstan, and Mongolia. Some railways in Poland are the wide-gauge railways. Their main function is to import coal and iron resources from Ukraine. Russia has the longest Soviet gauge railway network, extending for $105,000 \mathrm{~km}$ and accounting for $60.2 \%$ of the Soviet gauge railway in Eurasia. The Ukrainian and Kazakh wide-gauge railways are the second-longest, accounting for $12 \%$ and $10.7 \%$ of the Soviet gauge railway in 
Eurasia. The length of the wide-gauge railways in 13 countries, including Belarus, Latvia, and Lithuania, is less than $4 \%$ of the Soviet gauge railway in Eurasia. The gauge width of this railway is $1524 \mathrm{~mm}$, and is also known as the "Finnish gauge." This type of railway is only distributed in Finland, but it can be directly connected to railways with a track width of $1520 \mathrm{~mm}$. Railways with a gauge width of $1676 \mathrm{~mm}$ are distributed in India, Pakistan, and Sri Lanka. This type of railway in India has the widest distribution $(43000 \mathrm{~km})$ and accounts for the highest proportion of the national railway network $(81.5 \%)$. Therefore, this gauge width is also called "Indian gauge." The gauge of the Irish railway is relatively independent, with a gauge width of $1600 \mathrm{~mm}$ that is known as the "Irish gauge." Besides, 1665 and 1674 $\mathrm{mm}$ gauge width railways are distributed in Portugal and Spain, respectively, with the former commonly known as the "Iberian gauge." (3) Narrow gauge railways are distributed throughout 15 countries, accounting for $15.6 \%$ of the Eurasian countries, mainly in Southeast Asia ( $\mathrm{Ba}$ et al., 2009). Among them, the most commonly used gauge widths are 1000 $\mathrm{mm}$ and $1067 \mathrm{~mm}$. A railway with a gauge width of $1000 \mathrm{~mm}$ is referred to as a meter-gauge railway. It is mainly distributed in nine Eurasian countries, of which India has the largest proportion (29.4\%). Thailand, Myanmar, Vietnam, and Bangladesh account for a further 10\%-19\%, while Malaysia accounts for $7.9 \%$, and there are lesser amounts in Cambodia, Singapore, and Nepal. A gauge width of $1067 \mathrm{~mm}$ is commonly known as "Cape gauge," and is used in five countries/regions. Japan has the longest railway network with this gauge width at $28,000 \mathrm{~km}$, accounting for $74.1 \%$ of the total. In Indonesia, the proportion is $13.9 \%$, and the Philippines, Sakhalin (Russia), and Taiwan (China) are all above 3\%. The $1050 \mathrm{~mm}$ gauge width railway is mainly distributed in Jordan, while the $760 \mathrm{~mm}$ gauge width railway is concentrated in India. In China, there are some railways with a gauge width of $762 \mathrm{~mm}$. The former Soviet republics have built some narrow-gauge railways, mainly for the timber, peat, and coal industries. Among them, there are 13,900 km of narrow-gauge forestry railways, and $90 \%$ of the nation's peat is transported by the narrow-gauge railways. (4) The track gauge width of $1435 \mathrm{~mm}$ is called the "standard-gauge". It is the most widely distributed gauge width and is used in more than 40 countries, i.e., $41.7 \%$ of the Eurasian countries. This type of railway has a length of $83,000 \mathrm{~km}$ in China, accounting for $21.8 \%$ of the total mileage of the Eurasian continental railroad track. It is also widely distributed in Germany and France, accounting for $13.09 \%$ and $11.05 \%$ of the Eurasian continental railroad track, respectively. In Poland, Italy, Britain, and Sweden together it accounts for between 5\% and $8 \%$ of the Eurasian continental railroad track, while in Romania, Turkey, Hungary, Austria, Iran, Czech, Norway, Switzerland, DPRK, Serbia, Belgium, Bulgaria, Slovakia, and the Netherlands it exceeds $1 \%$ of the total. In contrast, in 20 other countries, including Iraq, Denmark, South Korea, Croatia, and Greece, the corresponding figure is below 1\%. (5) The railways with the mainstream gauge widths form the regional networks in most countries, while railways with other gauge widths form special lines for specific functions, with very few countries having multi-gauge width regional networks. India is a special case with three main gauge widths of $1676 \mathrm{~mm}, 1000 \mathrm{~mm}$, and $760 \mathrm{~mm}$. The $1676 \mathrm{~mm}, 1000 \mathrm{~mm}$, and 760 mm gauge width railways account for $84 \%, 12.3 \%$, and $3.7 \%$ of the total, respectively. 


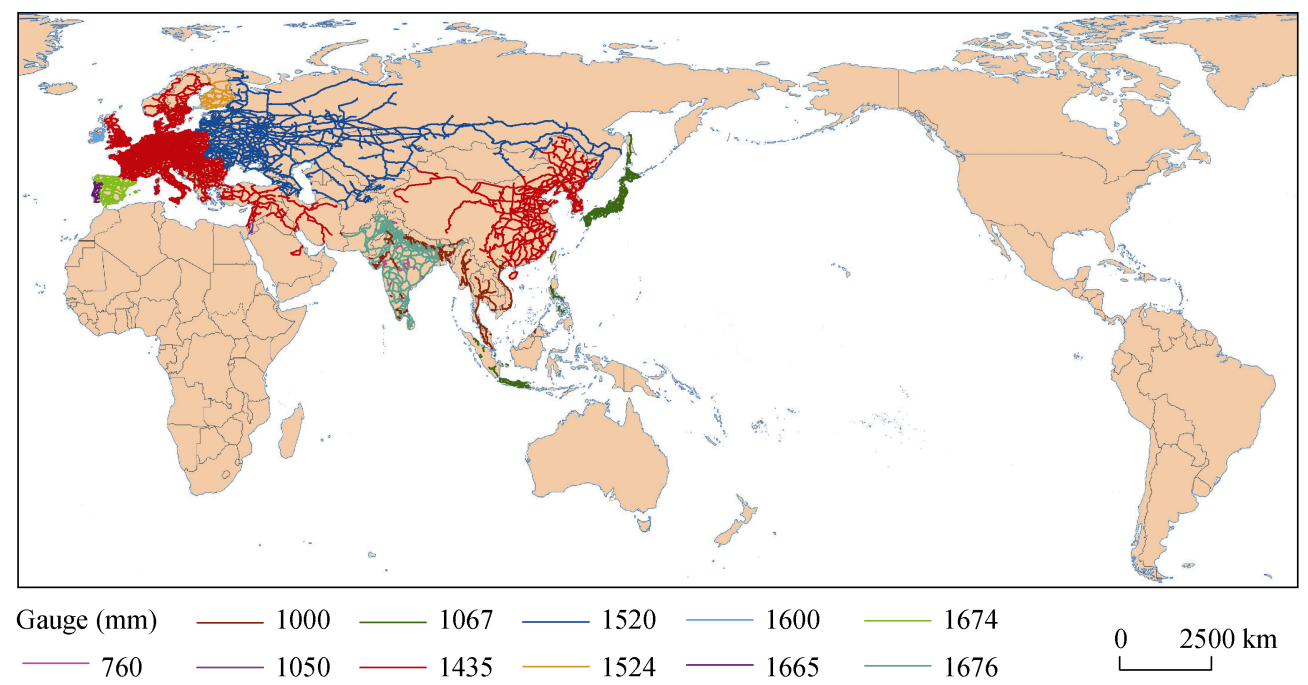

Figure 2 Spatial distribution of railways with different gauges in Eurasia

\section{Geo-system of the Eurasian railway network}

\subsection{Railway geo-system differentiation}

The geopolitical pattern is initially manifested in spatial politics, i.e., the competition for spatial control capability. Certain physical facilities are required to control a geographical space, and transportation networks can closely control space and power. The integration of railway connectivity and networks has promoted the quiet evolution of the concept of national borders, causing spillover effects beyond physical boundaries, including human rights, as well as military, social, cultural, and other elements, which have changed the geographical relationship between states ( $\mathrm{Lu}, 2005)$. The effect of the regional integration of railway networks is significant, surpassing the role of other factors to become the focus of geo-competition (Figure 3). (1) From the distribution pattern of the Eurasian track gauges, under the principle of geographical proximity and gauge similarity, while ignoring the internal differences within individual countries, the railway network has resulted in the formation of eight geo-systems: three standard-gauge systems, three wide-gauge systems, and two narrow-gauge systems. Each rail system is not only a purely technical system but is also a geopolitical space containing political codes, political economy, and ideological connotations. Through the network properties of the dotted line and the lined surface, the railway network has promoted the formation of an organic whole, although its internal factors interact with each other (Li et al., 2016). This reflects the complexity of the geographical pattern of the Eurasian continent and the spatial inconsistency between national and geopolitical boundaries (Saul, 1973). (2) A geopolitical system has arisen in Eurasia with railways that have different gauge widths being located in different locations, which reflects the separation of various territorial forces and control ranges. A geographically based confrontation has developed based on track gauge widths, which has lasted for two centuries (Wei, 2017). "Continuous filming" is the core feature of the railway geographic network. Different geopolitical systems have failed to produce complex staggered or blended distributions. This 
indicates that the level of inter-penetration and cross-interference of geo-industrial forces is relatively low. (3) The integrity of the railway geo-system is significant, and islanding is not obvious. The unity of neighboring countries is an important feature, which is determined by their shared geographical problems and the technical and economic attributes of railway transportation. The former requires the formation of a continuous geographical group, while the latter requires a reduction in transportation costs and the formation of a regional market. Most railway geo-systems are located in the marginal areas of Eurasia rather than being isolated in inland areas, but some countries in the Middle East and South Asia have developed obvious islanding or embedding patterns (Li, 2009). (4) Railway geo-systems can be differentiated into "leading countries" and "following countries." A leading country plays a role in the formulation, dissemination, and dominance of the regional railway network. Historically, a country would be recognized as a "following country" before developing into a "leading country." This identity has been strengthened and extended to form the current geographical pattern. This phenomenon is evident in the Soviet wide-gauge rail system and the British standard-gauge rail system. However, some geo-systems do not result in the formation of a dominant country, and the differences between countries are small. Therefore, the choice of track gauges is subject to geographical influence. (5) The boundaries of the major railway geo-systems act as buffer zones in the historical political systems of various regions, but there are slight differences in these areas. Some of the border areas are located in typical geopolitical centers, especially in Central Asia, because this area is the junction of several different railway geo-systems and is also a core area of land rights doctrine. Besides, the Bay of Bengal region, which is the buffer zone between the Indochina Peninsula and the Indian Peninsula, has also become an important area for the intersection of railway geo-systems. The existence of various railway geo-systems and their competition or cooperation indicates that the coordinated development of Eurasian railways has not been achieved (Li et al., 2016).

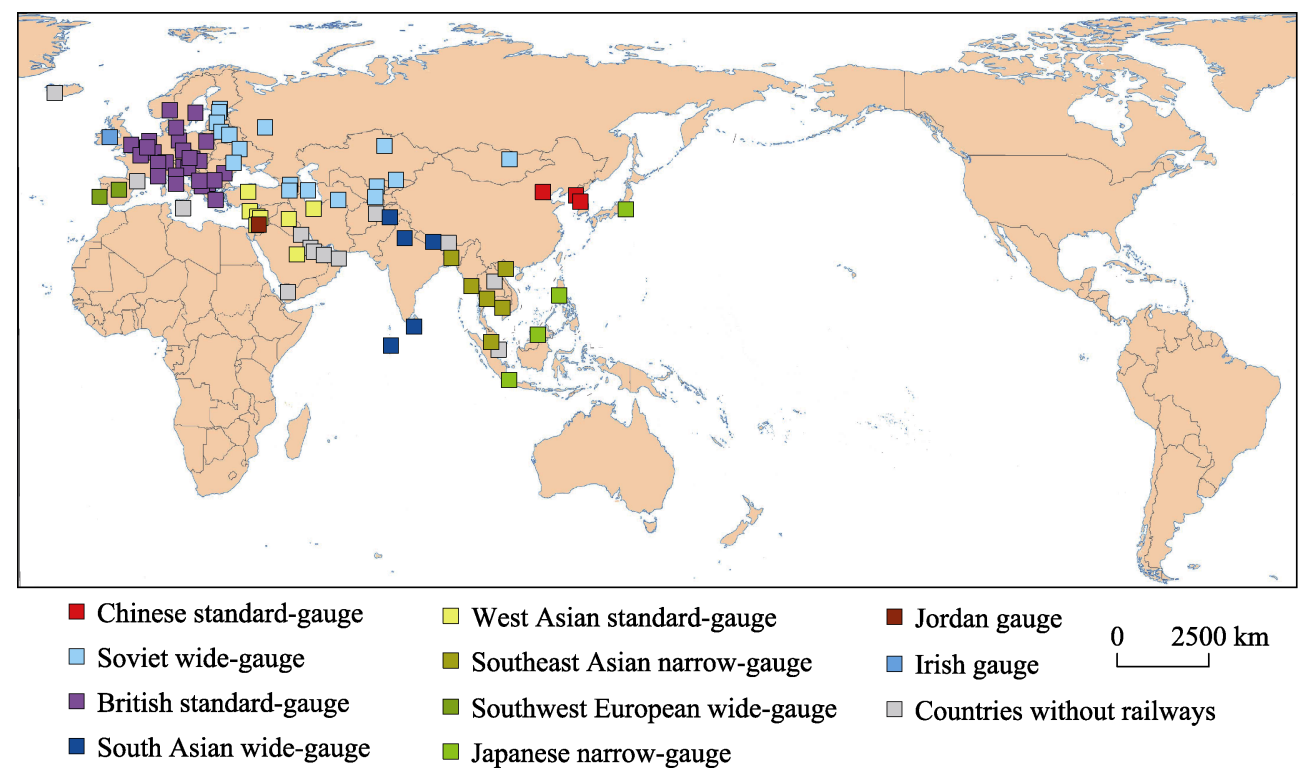

Figure 3 Spatial distribution of railway gauge geo-systems in Eurasia 


\subsection{Railway geo-system characteristics}

Figure 4 shows the geographic pattern of track gauge widths in Eurasia and the distribution of railway transportation organizations. Table 1 lists the constituent countries of the Eurasian railway geographic network. Specifically, the characteristics of each railway geo-system are as follows.

Table 1 The composition of railway geo-systems in Eurasia

\begin{tabular}{|c|c|c|}
\hline Gauge & Number & Country \\
\hline British standard-gauge system & 29 & $\begin{array}{l}\text { Russia, Armenia, Azerbaijan, Belarus, Bulgaria, Estonia, Georgia, } \\
\text { Kazakhstan, Kyrgyzstan, Latvia, Lithuania, Finland, Ukraine, } \\
\text { Moldova, Mongolia, Uzbekistan, Turkmenistan, Tajikistan } \\
\text { Denmark, Norway, Sweden, Poland, Czech, Slovakia, Hungary, } \\
\text { Germany, Austria, Liechtenstein, Switzerland, Netherlands, Bel- } \\
\text { gium, Luxembourg, United Kingdom, France, Monaco, Italy, } \\
\text { Vatican, Slovenia, Croatia, Bosnia and Herzegovina, Macedonia, } \\
\text { Romania, Bulgaria, Albania, Greece, Serbia, Montenegro }\end{array}$ \\
\hline Chinese standard-gauge system & 3 & China, DPRK, South Korea \\
\hline Southeast Asian narrow-gauge system & 7 & $\begin{array}{l}\text { Vietnam, Cambodia, Thailand, Malaysia, Myanmar, Bangladesh, } \\
\text { Singapore }\end{array}$ \\
\hline West Asian standard-gauge system & 7 & Iran, Iraq, Syria, Lebanon, Israel, Turkey, Saudi Arabia \\
\hline South Asian wide-gauge system & 3 & India, Pakistan, Sri Lanka \\
\hline Japanese narrow-gauge system & 6 & $\begin{array}{l}\text { Indonesia, Philippines, Japan, Taiwan (China), Brunei, Sakhalin } \\
\text { (Russia) }\end{array}$ \\
\hline Southwest European wide-gauge system & 2 & Spain, Portugal \\
\hline
\end{tabular}

(1) Soviet wide-gauge system. The system mainly covers Eastern Europe, Central Asia, West Asia, and the Far East. It is used in 18 countries, which account for $19.6 \%$ of all Eurasian countries but cover $44.2 \%$ of the land area. The countries are Russia, Armenia, Azerbaijan, Belarus, Bulgaria, Estonia, Georgia, Kazakhstan, Kyrgyzstan, Latvia, Lithuania, Ukraine, Moldova, Mongolia, Uzbekistan, Turkmenistan, Tajikistan, and Finland, all of which are geographically connected. The geopolitical system has a track gauge width of $1520 \mathrm{~mm}$. Although Finland has a $1524 \mathrm{~mm}$ gauge width when the gauge error is between 2 and $4 \mathrm{~mm}$ tracks can be directly connected, enabling Finland to operate in this system. The geographic length of the railway network is $186,300 \mathrm{~km}$, accounting for $26.3 \%$ of the Eurasian railway network. The $1520 \mathrm{~mm}$ gauge width is the standard for the wide gauge railway of the Soviet Union. It is an important tool used by the then Soviet Union to pursue land rights. The region in which this gauge width is used can, therefore, be referred to as the "1520 space." Russia, as the historical user and maintainer of the $1520 \mathrm{~mm}$ gauge width, still has the most wide-gauge railways.

(2) British standard-gauge system. The system is mainly distributed in Europe, especially in western, northern, and central Europe, covering 29 countries, accounting for $31.5 \%$ of the total land area of Eurasia. The countries are the United Kingdom, France, Belgium, Germany, Italy, Austria, Hungary, Czech, Poland, the Netherlands, Denmark, Sweden, Norway, Slovakia, Liechtenstein, Switzerland, Luxembourg, Monaco, Vatican, Slovenia, Croatia, Bosnia and Herzegovina, Macedonia, Romania, Bulgaria, Albania, Greece, Serbia, and Montenegro, Macedonia, Denmark, Sweden, and Norway. Among them, the Nordic countries form an integrated railway network within Western Europe through submarine railway tunnels. Although the geographic extent of the railway network covers only $6.9 \%$ of the region's land area, it accounts for $37.9 \%$ of the total length of the entire Eurasian network due to its highly 
developed nature and the dense road network. The region has created a good rail track consistency and formed a "1435 space," becoming the world's most important railway geo-system. The degree of railway integration in Europe is much higher than that in Asia and has been an important material basis for the development of the EU (Gan et al., 2010).

(3) Chinese standard-gauge system. This system is distributed throughout most parts of East Asia, including the Chinese mainland, DPRK, and South Korea. Although the number of countries using this system is small, the land area covered accounts for $18 \%$ of the total area of Eurasia and the length of railway using this system accounts for $13.2 \%$ of the total Eurasian network. The system adopts the $1435 \mathrm{~mm}$ gauge width standard and can be connected to the British standard-gauge system.

(4) Southeast Asian narrow-gauge system. The system is used in seven countries in Southeast Asia (Myanmar, Thailand, Cambodia, Vietnam, Malaysia, Bangladesh, and Singapore) and is also used in parts of India and Pakistan. The rail gauge width of the system is mainly $1000 \mathrm{~mm}$, and the length of the railway using this system accounts for $2.1 \%$ of the total Eurasian network and covers $4.7 \%$ of the region's land area. Historically, the area was dominated by French and British colonies, and part of the railway network was built by the colonial monarchy.

(5) West Asian standard-gauge system: This system is mainly distributed across West Asia and Central Asia, covering Iran, Iraq, Syria, Lebanon, Israel, Turkey, Saudi Arabia, and Palestine. The land area of these countries accounts for $9.5 \%$ of Eurasia, and the length of the railway accounts for $3.3 \%$ of the total Eurasian network. The system mainly uses a track gauge with a width of $1435 \mathrm{~mm}$. These countries used to be European colonies and their railway networks are therefore the result of the combination of the incorporation and subsequent modification of the British standard rail system.

(6) South Asian wide-gauge system. The system is mainly used in South Asia, including India, Pakistan, and Sri Lanka, which account for $7.6 \%$ of the Eurasian land area, while the length of the railway accounts for $8.6 \%$ of the total Eurasian network. Because the area was formerly a British colony, the system mainly has a gauge width of $1676 \mathrm{~mm}$. India has created a pattern of coexistence of various gauge railways. Among them, the wide gauge (1676 $\mathrm{mm}$ ) accounts for $50.6 \%$ of the national network, mainly connecting the major cities, coastal ports, and industrial centers. The railways with this gauge width are mostly electrified lines and are the transport artery of India. The meter-rail gauge width accounts for $42.2 \%$ of the rail network and is mainly distributed in the northern plains of Uttar Pradesh. The narrow gauge $(762 \mathrm{~mm})$ and light rail $(610 \mathrm{~mm})$ railways account for $7.2 \%$ of the total network and are mainly distributed in mountainous or mining areas.

(7) Japanese narrow-gauge system: This system is mainly used in Southeast Asia and the East Asian island countries and regions, specifically, Japan, Taiwan (China), Indonesia, the Philippines, Brunei and Sakhalin (Russia). The area of these countries accounts for $4.7 \%$ of the Eurasian land area, while the length of the railway accounts for $4.8 \%$ of the total Eurasian network. The system mainly has a gauge width of $1067 \mathrm{~mm}$, which is the standard for domestic railways in Japan. All of the areas using this system were Japanese colonies during the Second World War.

(8) Southwest European wide-gauge system. This system mainly covers the Iberian Peninsula, i.e., Spain and Portugal, and is located in the southwest of Europe. The area of these countries accounts for only $1.1 \%$ of the Eurasian land area, while the length of the railway 
accounts for $3.3 \%$ of the total Eurasian network.

\subsection{Geographical patterns of transport organizations}

A railway is a component of a nation's infrastructure. The trains in use on a railway are operated by transport organizations, and the allocation of train operating times and the rights to use certain railway facilities are features of effective transport management. This has enabled the differentiation of railway network facilities, operation networks, and management networks among countries. Differences in gauge distance and the splitting of railway networks does not necessarily result in differences in how transportation is conducted, but international railway transport networks are based on complex geographical relationships (Zeng et al., 2019). Table 2 shows the member states of Co-operation between Railways (OSJD) and The International Union of Railways (UIC). (1) Eurasia spans several jurisdictions, with numerous treaties that are incompatible with each other. Several different regulatory systems have been applied in international railway transport networks, enabling the formation of regional international railway organizations. Two major railway transportation management systems are operated by two major organizations, OSJD and UIC (Li, 2009). These two organizations have established Eurasian international railway transportation rules, including the legal system, technical standards, and customs procedures (Zeng et al., 2019). The two organizations have enabled the formation of four types of rail transport management area in the Eurasian continent: OSJD area, UIC area, the double-span area, and other areas. (2) The four major management areas have prominent geographical locations. Europe is a transportation management area dominated by the iron and steel industry. This is therefore largely "1435 space." UIC has formed a management area in some countries in Eastern Europe, East Asia, and Central Asia, mainly covering the "1520 space" and the Chinese standard-gauge system. A double-span area exists at the junction of the two major regions of OSJD and UIC. This mainly encompasses Russia, Eastern Europe, and parts of West Asia. Except for Russia, the area mostly covers buffer countries within the "1435 space" and "1520 space." The regions outside these management areas are mainly Asian countries, including the Arabian Peninsula, South Asia, Southeast Asia, and the Far East Islands. (3) There is a clear coupling relationship between the railway management areas and geopolitical activity, which is strongly influenced by geographical features. During the Cold War, OSJD and UIC were divided into different political camps. OSJD members were socialist countries and members of the Warsaw Pact Organization, while UIC members were capitalist countries and members of the North Atlantic Treaty Organization (NATO). (4) The spatial pattern of the railway management areas has undergone a historical evolution from the three regions in the 1980s. OSJD region was originally dominated by the Soviet Union and Eastern European countries, and later became dominated by the Soviet Union, Eastern Europe, and some Asian countries, with an expansion into some countries in Central and West Asia. In the early 1990s, the drastic changes in Eastern Europe and the disintegration of the Soviet Union led to changes in both OSJD and UIC member states. Many OSJD member states joined the UIC, forming a two-span region, which prompted the three regions to evolve into four railway management areas. The shrinkage of " 1520 space" and the penetration of " 1435 space" were the main trends occurring at this time. (5) The evolution of the railway management areas has occurred through a process of change from "confrontation" to "fusion." 
The International Railway Freight Transport Agreement and The International Convention on Railway Freight Transport are the main international transport treaties. The former was adopted by the iron group and the latter was adopted by the iron joint. The two systems together constrain the Eurasian transnational railway transport organization. This has led to the incompatibility of shipping rules, transport documents, the scope of applications, division of duties, and compensation (Zeng et al., 2019). This resulted in an obvious "transportation confrontation" and "cutting evidence." In the 1950s, OSJD and UIC began to implement an "East-West approach" but progress was limited. In the 1990s, the Customs Transit Convention was signed and a unified customs clearance document standard was implemented. In 2006, the Agreement on the Organization and Operation of Eurasian Intermodal Multimodal Transport was concluded, and a unified air waybill was introduced, although some countries did not adopt the unified waybill until 2009 (Li, 2011).

Table 2 Members of organizations for co-operation between railways and International Union of Railways

\begin{tabular}{|c|c|c|}
\hline International organization & Co-operation between railways (OSJD) & The International Union of Railways (UIC) \\
\hline Number of member states & 27 & 46 \\
\hline Name of member states & $\begin{array}{l}\text { Azerbaijan, Albania, Afghanistan, } \\
\text { Belarus, Bulgaria, Hungary, Vietnam, } \\
\text { Georgia, Iran, Kazakhstan, China, } \\
\text { DPRK, Kyrgyzstan, Latvia, Lithuania, } \\
\text { Moldova, Mongolia, Poland, Russia, } \\
\text { Romania, Slovakia, Tajikistan, } \\
\text { Turkmenistan, Uzbekistan, Ukraine, } \\
\text { Czech, Estonia }\end{array}$ & $\begin{array}{l}\text { Albania, Armenia, Austria, Belgium, Bosnia and } \\
\text { Herzegovina, Bulgaria, Croatia, Czech, } \\
\text { Denmark, Estonia, Finland, France, Germany, } \\
\text { Georgia, Greece, Hungary, Iran, Iraq, Ireland, } \\
\text { Italy, Latvia, Lebanon, Liechtenstein, Lithuania, } \\
\text { Luxembourg, Macedonia, Monaco, Montenegro, } \\
\text { Netherlands, Norway, Pakistan, Poland, Portugal, } \\
\text { Romania, Russia, Serbia, Slovakia, Slovenia, } \\
\text { Spain, Sweden, Switzerland, Syria, Turkey, } \\
\text { Ukraine, United Kingdom, Jordan }\end{array}$ \\
\hline Observing country & $\begin{array}{l}\text { Germany, France, Greece, Finland, } \\
\text { Serbia, Hungary, Austria }\end{array}$ & - \\
\hline Double transnational & \multicolumn{2}{|c|}{$\begin{array}{l}\text { Bulgaria, Czech, Estonia, Georgia, Hungary, Iran, Latvia, Lithuania, Poland, Romania, } \\
\text { Russia, Slovakia, Ukraine, Albania }\end{array}$} \\
\hline
\end{tabular}

\section{The formation mechanism of the Eurasian railway geo-system}

From the perspective of long-term sequences, the construction and development of different gauge railway networks and even spatial models are rooted in the changing historical background and geopolitical environment. This is the basis for understanding different geo-systems in the Eurasian railway network.

\subsection{Technological development and path dependence}

The initiation and expansion of industrialization has followed a certain historical and spatial path, which has had an important impact on the history of railway construction and the choice of track gauges used. Besides, it has played a fundamental role in the formation of the current railway geo-system. (1) The desirable characteristics of "connected into a network" have prompted neighboring countries to promote the construction of a unified gauge railway and form a continuous communication expansion model to establish a railway geo-system. The main period of railway construction was from 1825 to 1850 , and the main regions where railways were constructed were European countries, such as the United Kingdom and Germany. The period of industrial development was from 1850 to 1900, and the railways of in- 
dustrially advanced countries formed at different scales in Europe. The mature period was from 1900 to 1950, when most new railways were distributed in the Middle East, but some colonial countries also began to build railways at this time, based on a new technical standard of the rails. After 1950, railway construction in colonial countries and China entered a new period of development. Most European countries used standard rails in the early stages of railway construction. Europe, therefore, created a unified standard gauge system, which is referred to as the "1435 space" and these standards then spread to East and West Asia. (2) Throughout the history of railway construction, the spread of technology has increased. The Chinese railway was built by British engineers, and the track gauge width standard was consistent with that of the United Kingdom. This resulted in Chinese railways being standardized before the Republic of China was established. Therefore, China became the only country in East Asia to adopt the standard track, although it later spread to the Korean Peninsula. The Soviet-style wide gauge system was closely related to Russia's early Nicolaie railway construction period. American Joe acted as a technical consultant and suggested the 1520 $\mathrm{mm}$ gauge that was prevalent in the southern United States at the time, which laid the foundation for the development of "1520 space." (3) There are obvious "path dependence" characteristics during the network expansion of single-track railways. In the early days of railway construction, different countries chose different railway standards because of differences in their national interests. Once a track standard was determined, a railway system was formed. Once a certain construction path using a certain rail standard was established, the cost of changing certain aspects of railway projects, such as the original track, the bridges along the line, the tunnels, the locomotives to be used, and the station yard became very high, and therefore a dependence on the original path rapidly developed (Ba et al., 2009). Russia initially copied the railway tracks in the southern United States. After forming a certain scale of railway, this could not be changed. Therefore, the then Soviet Union inherited a wide gauge railway network and continued to expand it. (4) The pattern of track gauge widths and the formation of the railway geo-system developed over a historical sedimentation process that lasted for 200 years. Eurasia has formed the railway geo-systems based on different track gauges for various historical reasons. However, the two systems, i.e., "current one" and "historical one," are incompatible. Not only are the track gauges different in different countries, but also the track gauges within individual countries can vary. The current system does not account for changes that have occurred in the process and gives more attention to the final results, but in the process, the gauge width of the railway has been transformed in many countries. The various gauge railways built in the early stages were gradually transformed into mainstream gauges to form a unified rail network in the latter stages of national construction. After establishing a standard gauge of $1435 \mathrm{~mm}$, the United Kingdom gradually transformed a variety of gauges (1422 mm and $1372 \mathrm{~mm}$ ) into standard gauges in the 1890s. In continental Europe, France, Belgium, and other countries initially adopted a rail with a gauge width of $1500 \mathrm{~mm}$. Austria and the Netherlands used a rail with a gauge width of $1000 \mathrm{~mm}$. The Netherlands also operated a rail with a width of $1945 \mathrm{~mm}$ from 1839 to 1866 . Germany originally adopted a width of $1435 \mathrm{~mm}$. However, these countries have gradually transformed their railways into a standard track to connect to the wider network and coordinate with each other. At the time of the establishment of the Republic of China, a variety of gauge railways coexisted, including 1000, 1435, and $1520 \mathrm{~mm}$. Middle East track gauges 
with a width of $1520 \mathrm{~mm}$ became popular in Russia. Japan converted the Changchun-Lushun Railway into a standard gauge in 1907 and then converted the Harbin-Changchun and Manzhouli-Suifen sections into a standard gauge from 1935 to 1937. In the 1930s and 1940s, Japan built several railroads with a gauge width of $1067 \mathrm{~mm}$ in northeastern China, north China, and Hainan, with a total length of about 5,600 km, which were later converted to standard gauges.

\subsection{Geopolitics and military transportation}

The development of navigation, railway, aviation, and other technologies has led to the emergence of theories of land rights, air rights, and even outer space rights, which have built upon the existing theory of sea power (Wan, 2009). Railways are transportation modes with large traffic volumes and a high safety factor. They have always been the preferred method of military transportation. The national defense and military attributes of a railway determine its ability to become a powerful tool for national security and international geopolitical activity. Therefore, maintaining national security and expanding international influence has been an important criterion in the selection of railway systems, with geopolitical interests reflected in the construction of many major railways. (1) Railways play an important role in controlling territory and conducting warfare. To prevent the infiltration of neighboring countries or the intrusion of other military forces, a railway track that is designed by taking into account those of different neighboring countries, especially enemy countries, can be used to build a relatively independent railway network on a national basis. This is fully reflected in railway construction in Russia. In the 19th century, Russia chose a British railway system, with a gauge width of $1524 \mathrm{~mm}$, and subsequently converted it into a railway with a gauge width of $1520 \mathrm{~mm}$. The purpose of the conversion was to form a split with the standard gauge railway network of other European countries to ensure military security. This strategy played an important role during the Second World War. Germany was defeated in the war in Moscow because of the insufficient supply of materials. One important reason for this was the incompatibility between the railway tracks of the two countries and the destruction of the rail-conversion facilities by the Soviets. The original intention behind Russia's construction of the Siberian Railway was also part of a military strategy and satisfied the nation's geopolitical needs, which were aimed at preventing the invasion of enemy countries from the Far East and Central Asia; thus safeguarding the security of Siberia and the Far East (Ren, 2009). During a period of tension in the relationship between China and the Soviet Union, the entire Jining-Erenhot Railway line was changed from a $1520 \mathrm{~mm}$ gauge width to $1435 \mathrm{~mm}$. For the same reasons, the handover of equipment was moved from Jining Station to Erenhot in 1965. (2) Technology links space and power closely (Lu, 2009). The extension of a nation's railway network symbolizes the expansion of the country's development space and provides economic, political, and ideologic drivers to spread and radiate development throughout geographical space ( $\mathrm{Li}$ et al., 2016). This creates a complete area of interest and promotes the change and reshaping of the geopolitical pattern. The development of railways began to impact on the advantages of sea power in the early 20 th century, and therefore Eurasia gradually became the focus of geo-competition. The intercontinental railway network can change the power structure on land. In Central Asia, land rights are more significant than sea power, and countries that control land in Central Asia through land 
transportation are more likely to become world powers (Mackinder, 2004). This assertion supported the "same train and railroad" strategy of the then Soviet Union during the Cold War. The gauge width selection criteria became a means for countries to formulate geopolitical rules that defined their interactions, and also influenced the spatial forms and patterns of geopolitical relations ( $\mathrm{Li}, 2009)$. In the early days of railway construction, the gauge width of the railroad tracks in Eastern Europe was $1435 \mathrm{~mm}$. The Soviet Union promoted a wide gauge railway strategy in Eastern European countries, Poland, and their allies, which enabled them to control Eastern Europe and compete for power elsewhere in Europe (Li, 2016). The railways of Poland, Mongolia, and other former Soviet republics are mainly wide gauge. The width of the $1520 \mathrm{~mm}$ gauge railway is not only popular in the Soviet Union and Finland, but also penetrates Poland, Slovakia, and Romania, thus, forming the "1520 space." There is a distinct confrontation between the "1520 space" and "1435 space" (Li, 2009).

\subsection{Colonial expansion and colonial rule}

Both railways and colonies are the result of capitalist industrialization. Due to the rapid industrialization and population increase in Europe, the demand for mineral resources and industrial products has increased, which has led to the world being divided, and many countries in Asia have been forced to become colonies or semi-colonies. The railway network has played an important role in colonial expansion and rule by European countries. Table 3 shows the rail gauge relationship between sovereign states and the colonial powers in Eurasia. (1) The construction of a railway is the basis for a sovereign state to rule in a colony. Beginning in the 1840s, the United Kingdom began building railways enabling it to plunder raw materials (such as cotton) and natural resources. The United Kingdom built a cross-shaped railway that runs through the South Asian subcontinent and subsequently further built a large-scale railway. The length of the British Indian Railway was about 42,000 $\mathrm{km}$ in 1900, slightly less than the network length in the United States, Canada, and Russia. (2) Some non-colonial countries have built railroads with the same gauge as their neighboring colonized countries. The purpose of this was to use the railway as a springboard for expansion, to conduct epitaxial expansion, and to enable colonial infiltration based on the existing colonies. After the China-France war, France planned to build the Beibu Gulf Railway, which was planned to run through the ports and cities of the Indochina Peninsula and extend to Yunnan, Guangxi, and Guangdong. In 1910, France built the Yunnan-Vietnam Railway, with a gauge width of $1000 \mathrm{~mm}$. This increased the influence of France in Yunnan and provided an opportunity to develop the rights of Yunnan. In 1898, after the construction of the Siberian Railway, Russia forced the construction of the Middle East Railway and the South Manchu Railway in China. The gauge width of these railways was $1520 \mathrm{~mm}$. (3) Sovereign states in Eurasia have implemented a leap-style development of railways within the colonies or their sphere of influence, to meet their needs for material transportation and to resist external invasion. In 1846, the British identified the $1435 \mathrm{~mm}$ gauge width as a standard gauge and extended it to their colonies and spheres of influence. The United Kingdom built a large number of railways in their colonies, which prompted many countries to adopt their standard track gauge. In the 1860s, with Finland being a vassal state of Russia, Russia extended its $1524 \mathrm{~mm}$ gauge railway to Finland. This gauge width is still in use in the current Finnish rail network. The Tanggu Line was the first railway built in China. It was built by British engineers using the $1435 \mathrm{~mm}$ gauge standard, which laid the path for the Chinese standard-gauge 
system. From 1907 to 1947, the Japanese built $754 \mathrm{~km}$ of railway in China and some further railways in Sakhalin. The gauge width of these railways was $1067 \mathrm{~mm}$. (4) It is common for railways with different gauges to be located within a certain country or a certain sphere of influence. However, a certain gauge width is often dominant within an individual country and railways with other gauge widths are only used for special functions or are distributed in special areas. Some special phenomena need to be considered. For example, in India, the length of railways with different gauges is similar, and the differences between them are small. During the colonial period, the construction of the Indian railway was undertaken by various private companies. Competition between these companies led to differences in the gauge width of the track. This historical legacy led to the existing pattern in which there is a coexistence of various gauge widths (Hu et al., 1986). India has become a multi-track country. (5) In many previously colonized countries, the sovereign states have chosen to build narrow-gauge railways to reduce investment and cost (especially in hilly areas), accommodate a small radius of curvature on bends, large route gradients, and reduce the locomotive power that is required. This is the case in Southeast Asia. The United Kingdom did not set standards for the construction of railways in its colonies after it established the $1435 \mathrm{~mm}$ standard gauge railway. Most of the Southeast Asian railways were built during the period of British and French colonial rule (Nie et al., 2012). The railways in the French colonies (e.g., Vietnam, Laos, and Cambodia) were all one meter wide, while the railways in the British colonies (e.g., Myanmar and India) were not all one meter wide.

Table 3 Railway gauge relationships between the suzerain and the colony in Eurasia

\begin{tabular}{|c|c|c|c|c|c|c|c|c|}
\hline \multirow{2}{*}{ Colony } & \multirow{2}{*}{$\begin{array}{c}\text { Gauge } \\
(\mathrm{mm})\end{array}$} & United Kingdom & France & Japan & United States & Turkey & Netherlands & Vietnam \\
\hline & & 1435 & 1435 & 1067 & 1435 & 1435 & 1435 & 1000 \\
\hline Philippines & 1067 & - & - & $1942-1945$ & $\begin{array}{c}1898-1935 \\
1945-1946\end{array}$ & - & - & - \\
\hline Malaysia & 1000 & $\begin{array}{l}1826-1942, \\
1945-1957\end{array}$ & - & $1942-1945$ & - & - & - & - \\
\hline Myanmar & 1000 & $\begin{array}{c}1885-1942 \\
1945-1948\end{array}$ & - & $1942-1945$ & - & - & - & - \\
\hline Singapore & 1435 & $\begin{array}{l}1824-1942 \\
1945-1957\end{array}$ & - & $1952-1945$ & - & - & - & - \\
\hline Sri Lanka & 1676 & $1815-1948$ & - & - & - & - & - & - \\
\hline India & 1676 & 1849-1947 & - & - & - & - & - & - \\
\hline Pakistan & 1676 & 1849-1947 & - & - & - & - & - & - \\
\hline Bangladesh & 1676 & $1757-1947$ & - & - & - & - & - & - \\
\hline Jordan & 1050 & 1918-1946 & - & - & - & 1516-1918 & - & - \\
\hline Iraq & 1435 & $1918-1932$ & - & - & - & 1534-1918 & - & - \\
\hline Israel & 1435 & $1917-1948$ & - & - & - & 1516-1916 & - & - \\
\hline DPRK & 1435 & - & - & $1910-1945$ & - & - & - & - \\
\hline South Korea & 1435 & - & - & 1910-1945 & - & - & - & - \\
\hline Taiwan, China & 1067 & - & - & $1895-1945$ & - & - & - & - \\
\hline Thailand & 1000 & - & - & 1941-1945 & - & - & - & - \\
\hline Vietnam & 1000 & - & $\begin{array}{l}1884-1940 \\
1945-1954\end{array}$ & $1940-1945$ & - & - & - & - \\
\hline Cambodia & 1000 & - & $\begin{array}{c}1863-1940 \\
1945-1954\end{array}$ & 1945-1945 & - & - & - & 1979-1989 \\
\hline Indonesia & 1067 & - & - & $1942-1945$ & - & - & $\begin{array}{l}1610-1942, \\
1945-1954\end{array}$ & - \\
\hline Syria & 1435 & - & $1918-1946$ & - & - & 1516-1916 & - & - \\
\hline Lebanon & 1435 & - & $1918-1943$ & - & - & 1516-1916 & - & - \\
\hline
\end{tabular}




\section{Geographical model of the Eurasian track gauge width}

The countries that originally developed track gauge standards have different political systems, geographic locations, levels of railway connectivity, and technical standards, which has resulted in different communication or expansion paths and internal dynamic mechanisms. Based on this, we propose several geographical models, as shown in Figure 4, including a continuous expansion model, core-edge model, colonial dispersion model, colonial continuous model, and colonial jump model. Table 4 compares different rail gauge expansion models in terms of seven aspects.

Continuous expansion model: All countries and regions involved have adopted a unified track gauge standard. There is spatial continuity in the terrestrial area and the railways are interconnected to form a unified network. The status of the country's railway technology is relatively similar. There is no differentiation between the leading and the following countries. The gauge standard is the result of its natural spread throughout the region. A typical case of this model is the EU region, which forms the "1435 space."

Core-edge model: The countries involved have spatial continuity in their geography, forming a uniform gauge standard based on a standard dominant country. Countries can be classed as leading, closely linked, or loosely connected. The leading countries have the role of disseminating the gauge standards and the function of formulating the rules. A unified railway network is formed between the leading countries and the closely connected countries, and connecting channels of the same gauge are formed between the leading and loosely connected countries. A typical case of this model is the Soviet-style wide gauge system, which has resulted in the differentiation of Russia, its republics, and allies. Russia is a leading country. Its standards are mechanical and rely on a compulsory approach to ensure its spread. This model forms the "1520 space."

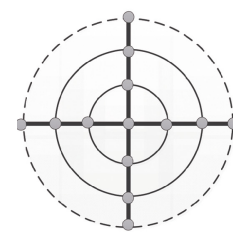

Continuous expansion model

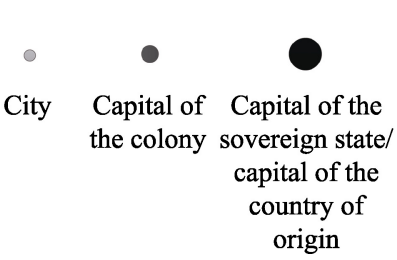

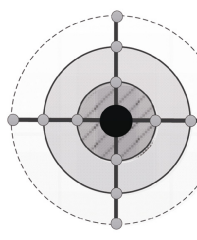

Core-edge model

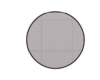

Colony
Sovereign country

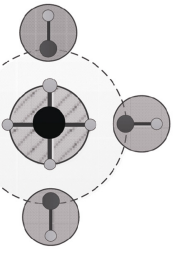

Colonial decentralized model

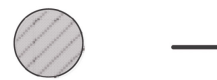

Railway of Rail gauge

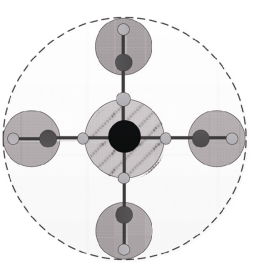

Colonial continuous mode

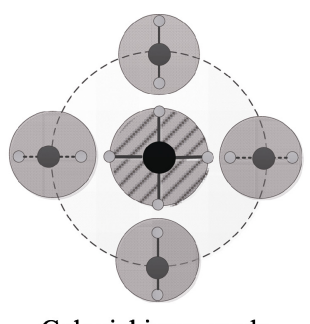

Colonial jump mode

Figure 4 Expansion models of the track gauge standard in Eurasia

Colonial decentralization model: Differences between sovereign and colonized states are formed based on historical attributes. These two types of countries have a continuous geographical extent across sea and land, but there is spatial segregation on land. This spatial separation does not occur between countries. This results in a unified gauge standard among 
different countries but does not form an interconnected railway network. The sovereign state is not only the propagator of the standard colonial gauge but is also the builder of the railway infrastructure. The sovereign state has the dominant power, although the colony is accepted. Therefore, the dissemination of the standard gauge is mandatory. A typical case of this model is the Japan-Far East Island region. Japan is a sovereign state, and other countries in this region were its colonies. The discrete "1067 space" formed under this model in this region.

Colonial continuous model: There is continuity of land area between a sovereign state and a colony. Under the premise that different countries adopt the same gauge standard, their railways are connected and form an integrated network. This model is similar to the colonial decentralized model. It is expressed in the active and passive relationship between a sovereign state and a colony. The dissemination of the standard gauge is mandatory. A typical case of this model is Turkey-Israel, and the typical geo-system where this model is adopted the West Asian standard-gauge system.

Table 4 Comparison table of railway gauge expansion models

\begin{tabular}{|c|c|c|c|c|c|c|c|}
\hline Model & Location & Gauge & Network & Differentiation & Mechanism & $\begin{array}{c}\text { Gauge } \\
(\mathrm{mm})\end{array}$ & Case \\
\hline $\begin{array}{l}\text { Continuous } \\
\text { expansion model }\end{array}$ & $\begin{array}{l}\text { Geographical } \\
\text { connection }\end{array}$ & Same & Complete & Undifferentiated & $\begin{array}{l}\text { Natural } \\
\text { transmission }\end{array}$ & 1435 & EU \\
\hline Core-edge model & $\begin{array}{l}\text { Geographical } \\
\text { connection }\end{array}$ & Same & Complete & Differentiation & $\begin{array}{l}\text { Mechanical } \\
\text { propagation }\end{array}$ & 1520 & Soviet Union \\
\hline $\begin{array}{l}\text { Colonial decentraliza- } \\
\text { tion model }\end{array}$ & $\begin{array}{l}\text { Sea and land connec- } \\
\text { tion; Land isolation }\end{array}$ & Same & Detached & Differentiation & $\begin{array}{l}\text { Mechanical } \\
\text { propagation }\end{array}$ & 1067 & $\begin{array}{l}\text { Far East } \\
\text { Island }\end{array}$ \\
\hline $\begin{array}{l}\text { Colonial } \\
\text { continuous model }\end{array}$ & $\begin{array}{l}\text { Geographical } \\
\text { connection }\end{array}$ & Same & Complete & Differentiation & $\begin{array}{l}\text { Mechanical } \\
\text { propagation }\end{array}$ & 1435 & $\begin{array}{l}\text { Central and } \\
\text { West Asia }\end{array}$ \\
\hline $\begin{array}{l}\text { Colonial jump model } \\
\text { (Same gauge) }\end{array}$ & Land isolation & Different & Detached & Differentiation & $\begin{array}{l}\text { Mechanical } \\
\text { propagation }\end{array}$ & 1435 & $\begin{array}{l}\text { Central and } \\
\text { West Asia }\end{array}$ \\
\hline $\begin{array}{l}\text { Colonial jump model } \\
\text { (Different gauge) }\end{array}$ & Land isolation & Different & Detached & Differentiation & $\begin{array}{l}\text { Mechanical } \\
\text { propagation }\end{array}$ & 1000 & $\begin{array}{l}\text { Southeast } \\
\text { Asia }\end{array}$ \\
\hline
\end{tabular}

Colonial jump model: The sovereign state and the colonies are spatially separated from each other in terms of their geographic location. The railway networks formed by these two types of countries are relatively independent and not integrated. According to the differences in gauge standards, this pattern can form two cases. In one case, the gauge width used in the sovereign state is the same as that used in the colony. The gauge width used in the sovereign state is considered to be responsible for the spatial jump of the colonial standard gauge, with France-Syria being a typical example. The standard gauge is mechanically propagated. The typical gauge width is $1435 \mathrm{~mm}$. In the other case, the gauge width used in the sovereign state is different from that used in the colony. In this case, although there is a railway construction relationship, the two railways do not have the same gauge width, with France-Vietnam being a typical example. The typical gauge width is $1000 \mathrm{~mm}$.

\section{Conclusions and discussion}

\subsection{Research conclusion}

A railway is a basic material element of a country. It has impacts on many aspects of a nation, such as the social economy, national defense and military activity, and geopolitics. Railway facilities have the technical stipulation of its core facilities, which promotes the formation of unique attributes such as "network", "region" and "geography", etc. Differ- 
ences in the gauge widths of railways determine the fracturing of the railway network and the formation of the railway geo-systems and also shape the regional geopolitical pattern. The railway geo-system is an interactive and interdependent geo-environmental system that integrates railway, state, rights, space, economy, nature, society, national defense and military elements based on railway infrastructure network and railway transportation network in a specific region. The main features of the same railway technical standard are the formation of uniform transport rules, spatial interconnection, and continuous integration. The two kinds of development and safety needs coexist with each other in different railway geo-systems, which are mainly confrontation and cooperation. Since the middle of the 19th century countries have selected various track gauges when building railways because of differences in national conditions and external influences. The reasons for the differences in the gauge widths used in railways in Eurasia are complex. However, railways with a high degree of applicability and forming regional networks mainly have gauge widths between 610 and $2141 \mathrm{~mm}$ and are classified as wide, standard, or narrow gauge railways. This has led to a "fracture" phenomenon in the railway network, which has resulted in the incompatibility of transportation across the network. The 1435, 1520, and $1067 \mathrm{~mm}$ gauge widths are the main widths used in the Eurasian railway network. There is considerable variation in the level of railway coverage with different gauge widths. In Eurasia, the 1520-1524 mm wide-gauge railway is used in 18 countries, while the standard railroad track is used in 40 countries; the meter-gauge railway track is used in 10 countries, and railways with a track width of 1067 $\mathrm{mm}$ are used in seven countries. The difference in track gauges is a technical issue that determines how the railway system is formed and is also the physical basis for the formation of fractures in the railway network. The historical differences in track gauges have occurred as a result of long-term processes. Railways can combine space and political rights to form a geopolitical system that exceeds that of the state as a whole. Concerning railways, eight railway geo-systems have formed in Eurasia, including three standard gauge systems in Europe, China, and Central and West Asia, three wide-gauge systems in the Soviet Union, South Asia, and Southwest Europe, and two narrow gauge systems in Southeast Asia and the Eurasian islands. "Continuous filming" is the core feature of the railway geographic network. Different regions and various countries are separated and covered by the railway geo-system in Eurasia. The geo-system of some railways can be used to divide countries into leading and following countries. The boundary of various railway geo-systems defines an important geo-core area, especially the confrontation pattern between "1435 space" and "1520 space." Rail transport has also formed the OSJD and UIC geopolitical systems, although they have gradually become integrated. The construction and development of different gauge railway networks and spatial models is a consequence of changes in the historical background and geopolitical environment. Since the 19th century, the spread of technology, colonial rule, and national defense and military activity has led to the continuous expansion of the railway network, but has resulted in differences in track gauges. In the 20th century, colonial expansion, geopolitical conflict, path dependence, and modification led to a strengthening of the regional railway system and the formation of the Eurasian railway geo-system. The obvious geo-confrontational relationship between the "1520 space" and the "1435 space" has been particularly important in this process. Different track gauges have experienced a continuous expansion, with core-edge, colonial dispersion, colonial continuity, colonial jump, and other 
spatial patterns occurring in the process of their dissemination. Each of the five models considered in this study has different land-land relationships, network convergence, country differentiation, technology communication mechanisms, and gauge differences, which respectively reflect different railway geo-systems operating in the region.

\subsection{Discussion and prospects}

In the future, there are likely to be new trends in the construction of the Eurasian railway network and its geographical relationship, such as the reconstruction of "1520 space," the expansion of "1435 space," the mutual penetration and integration of the two spaces, the construction of standard railways in China and its neighboring countries, and the influence of track gauges on the geopolitical system in Afghanistan. (1) The standard gauge railway and the other gauge railways have exhibited some network crossover, which is mainly due to the construction of high-speed rail networks. Since the 1990s, Europe and China have begun to develop high-speed railways with standard gauges. Other countries are also interested in this type of railway and are trying to build high-speed railways to connect different regions, such as Moscow-Beijing and Beijing-Singapore. The high-speed railways intersect with the wide and narrow gauge railways passing through these countries, but they do not merge. The development of standard gauge high-speed railways will result in the intersection of various railway geo-systems (Nie et al., 2012). (2) The process of implementing standard gauge railways continues to advance. In some countries, new railways with standard gauges have been gradually adopted outside the existing rail systems, and they have even standardized the existing track gauges. A wide gauge railway was actively transformed into a standard gauge railway in Spain. The Baltic Railway Plan has also been implemented in the European Union. The transformation of the standard gauge railway has also been promoted in Lithuania, Latvia, and Estonia. This reflects an expansion of the "1435 space." (3) There has been a conflict between the expansion of the standard gauge railway and the geopolitical struggle that has existed for a long time, and which is likely to face greater geopolitical pressure in the future. In the future, the new railways connecting China with neighboring countries (e.g., China-Laos, China-Mongolia, China-Russia, and China-Kyrgyzstan-Uzbekistan) will use standard gauges. The planning and construction of these railways will exceed the boundary of "1520 space." However, in the face of the geopolitical pressure faced by these countries and the hesitation to pass through countries with historical grievances, ethnic disputes, and other issues, the current geopolitical pattern is difficult to overcome (Sun, 2016). The essence of geopolitics is control and demand. In contrast, China adheres to the geo-economic system and promotes the interconnection of railway networks. This has resulted in a significant contrast between the concepts of "inclusive development" and "controlling demand," and "economic cooperation" and "military confrontation." (4) The new geo-organization and railway standard system displays a coupling trend. The pursuit of geopolitical interests in different periods has generated a corresponding geopolitical pattern. The current geopolitical interests have driven the prevailing geopolitical pattern and railway grid bureau to form a coupling relationship. In 2015, the Eurasian Economic Union began to operate. The member states were Kazakhstan, Belarus, Russia, Armenia, and Kyrgyzstan, which have the same characteristics as the Soviet Union. At the same time, Russia has attempted to maintain the 
advantages of the "1520 space" and rebuild its sphere of influence through the "1520 mm Railway Cooperation Uniform Principle Statement." This has again resulted in a coupling trend with the Soviet-style wide-gauge railway system. Also, the "1520 space" was actively expanded, following the expansion of Eastern Europe, which had experienced an infiltration of "1435 space." In 2007, Russia and Austria signed a memorandum to consider the extension of the $1520 \mathrm{~mm}$ gauge railway from Bratislava to Vienna. (5) Afghanistan is currently considered to be the vacuum zone of the Eurasian railway network, and it will have a high reconfiguration effect on the railway geographic network because it is located in the heart of Asia. The countries bordering Afghanistan use three different gauge widths; Iran and China use standard-gauge systems, Pakistan uses the $1676 \mathrm{~mm}$ wide-gauge system, and Turkmenistan, Uzbekistan, and Tajikistan use the $1520 \mathrm{~mm}$ wide-gauge system. Building a railway here, regardless of which track gauge is chosen, will cause the geopolitical pattern to be reconstructed and become more complicated. This is a crucial factor affecting the Eurasian railway and Eurasian geopolitical relations (Zeng et al., 2019).

\section{References}

Ba H J, Guan W J, 2009. Different standard economic explanations of railway gauge. Journal of Dalian Maritime University, 8(5): 50-52. (in Chinese)

Bel G, 2011. Infrastructure and nation building: The regulation and financing of network transportation infrastructures in Spain from 1720 to 2010. Business History, 53(5): 688-705.

Che L, 2010. Yunnan railway network planning from the perspective of geopolitics in modern times. Journal of Qujing Normal University, 29(1): 115-120. (in Chinese)

Fan J, 2008. Economic geography and academic thinking of the regional system of man-land relationship. Economic Geography, 28(2): 870-878. (in Chinese)

Fan J et al., 2016. How Human Geographers Influence Decision Makers \& Society in China. Beijing: The Commercial Press. (in Chinese)

Gan J X, Mao Y, 2010. The revival of Silk Road: An analysis of China's high speed rail diplomacy. Pacific Journal, 7(7): 70-76. (in Chinese)

George C S L, 1999. Transportation and metropolitan development in China's Pearl River Delta: The experience of Panyu. Habitat International, 23(2): 249-270.

Hu S D, Pan W Z, 1986. Development of Indian railway. South Asian Studies Quarterly, 2(4): 56-59. (in Chinese)

$\mathrm{Hu}$ Z D, Cao Y, Liu Y L et al., 2013. A new development of political geography research in China: Geo-setting. Human Geography, 28(5): 123-128. (in Chinese)

Jin F J, Wang C J, Li X W et al., 2010. China's regional transport dominance: Density, proximity, and accessibility. Journal of Geographical Sciences, 20(2): 295-309.

Jin F J, Wang J E, 2004. Railway network expansion and spatial accessibility analysis in China: 1906-2000. Acta Geographica Sinica, 59(2): 293-302. (in Chinese)

Jing Z J, 2016. Analysis of Dugin's neo-Eurasianism geopolitical thought: A case study of Dugin's theory of multi-polar world. Russian Studies, 35(6): 60-90. (in Chinese)

Kolotov B H, 2016. Pang Changwei, Jia Xuechi, The Eurasian turbulent arc is a major geopolitical threat to integration. Academic Journal of Russian Studies, 6(3): 49-54. (in Chinese)

Li B B, 2016. An analysis of the geopolitical factors in the cold war between the United States and the Soviet Union: A case of Eurasia. Journal of Mudanjiang College of Education, 34(3): 19-20. (in Chinese)

Li B R, 2008. The role of railway in geopolitics and peripheral diplomacy. Railway Economics Research, 16(3): 8-12. (in Chinese)

Li B R, 2011. Impact of Eurasian railway network integration on China's railway development strategy. China 
Railway, 50(8): 1-2. (in Chinese)

Li J G, Tang S S, Jiang Z Y, 2007. Evaluation of military railway transport support capacity. Railway Transport and Economy, 29(9): 84-86. (in Chinese)

Li Z F, Wu L L, 2016. The geopolitical status of the Belt and Road and the Arctic Route with China from the perspective of transportation politics. Dongjiang Journal, 33(1): 55-62. (in Chinese)

Linneker B, Spence N, 1996. Road transport infrastructure and regional economic development: The regional development effects of the M25 London orbital motorway. Journal of Transport Geography, 4(2): 77-92.

Lu D D, 2002. Theoretical studies of man-land system as the core of geographical science. Geographical Research, 21(2): 135-145. (in Chinese)

Lu J Y, 2005. Technological factors in geopolitics. Journal of International Security Studies, 23(6): 7-12. (in Chinese)

Ma Y Z, Liu H R, 2010. The geo-strategic significance of Ganchuan-Chongqing: Lanzhou-Chongqing railway from the geographical perspective. Social Sciences Review, 25(7): 22-24. (in Chinese)

Mackinder H J, 2004. The geographical pivot of history (1904). Geographical Journal, 170(4): $298-321$.

Mao H Y, 1995. Study on the System of Man-land Relationship and Regional Sustainable Development. Beijing: China Science and Technology Press. (in Chinese)

Nie Y Y, Zhao L, 2012. China's geo-strategic reconstruction and regional political and economic value promotion in Southeast Asia: A concept of constructing Asian railway network. Academic Research, 55(3): 46-51. (in Chinese)

Ren X J, 2009. Siberian railway from the geoeconomic perspective. Academic Exchange, 25(4): 114-148. (in Chinese)

Saul B C, 1973. Geography and Politics in a World Divided. New York: Oxford University Press,.

Spence N, Linneker B, 1994. Evolution of the motorway network and changing levels of accessibility in Great Britain. Journal of Transport Geography, 2(4): 247-264.

Sun Z Z, 2016. Geopolitical game of cross-border traffic in central Asian countries. Journal of Xinjiang Normal University (Edition of Philosophy and Social Sciences), 37(2): 37-44. (in Chinese)

Wan Q, 2009. The impact of transportation technological development on geopolitics. Guide to Business, 10(12): 243-244. (in Chinese)

Wan Q S, 2016. Eurasian moment of great power politics: Evolution of Eurasian cognition and its implication from the perspective of geopolitical economy. Russian Studies, 35(1): 3-52. (in Chinese)

Wei J F, 2017. China-Laos railway and promotion of the geo-strategic value of Laos. South and Southeast Asian Studies, 35(4): 14-20. (in Chinese)

Wu C J, 1991. The core of study of geography: Man-land relationship areal system. Economic Geography, 11(3): 1-6. (in Chinese)

Zeng W G, Wang J N, 2019. Conflict and coordination of the Eurasian railway transport treaty system under the perspective of the Belt and Road. International Business Research, 40(1): 60-68. (in Chinese)

Zheng D, 1998. A study on the regionality and regional differentiation of geography. Geographical Research, 17(1): 5-10. (in Chinese)

Zhou J, 1990. On military economic management of railway military transportation. Military Economic Research, 11(4): 19-21. (in Chinese) 